\title{
Role of Internal Audit in Accounting Information Control in Public Departments: An Applied Study to the Sudanese Ministry of Interior (2009 - 2017)
}

\author{
Sana Ali Awad \\ Assist. Professor of Accounting, College of Administrative Sciences \\ Najran University, KSA \\ E-mail: drsano2016@gmail.com
}

Received: January 23, 2019 Accepted: November 4, 2019 Published: November 7, 2019

doi:10.5296/ijafr.v9i4.15779

URL: https://doi.org/10.5296/ijafr.v9i4.15779

\begin{abstract}
The study aimed to identify the role that internal audit plays in the control of accounting information provided by accounting agencies in public departments as well as the rules and bylaws adopted by the Internal Audit Chamber at the Sudanese Ministry of Interior. The study adopted the descriptive as well as historical approach to analyze the previous studies.

The study revealed that internal audit plays a role in keeping public funds, reducing the risks of theft as well as fraud, and evaluating accounting information. It recommends adopting modern methods in the current accounting system to evaluate and get the accurate as well as proper value of assets, and designing an effective internal audit system that serves to accomplish the desired objectives.
\end{abstract}

Keywords: Internal audit, Accounting, information, control, Sudanese Ministry of Interior

\section{Introduction}

The continuous development of economic activity in Sudan, the expansion of service projects, and the complexity as well as variety of operations increased the interest in internal audit and its effectiveness in the accuracy and credibility of accounting information in financial reports and protecting public money.

Accounting information has played an effective role in activating internal audit units as an evaluation method the public departments adopts to develop production efficiency. Internal audit has undergone significant development throughout the past two decades. Furthermore, it has evaluated the whole activities of public units. The development of internal audit 


\section{Ml Macrothink}

International Journal of Accounting and Financial Reporting

ISSN 2162-3082

2019, Vol. 9, No. 4

requires the scientific as well as practical rehabilitation of the internal audit departments to have the ability to control public money and to understand accounting information available in the public units' activities.

\subsection{Statement of the Problem}

Statement of the problem is defined in the following questions:

1. Does internal audit's role in the control of accounting information affect the financial performance in the Sudanese Ministry of the Interior?

2. Is accounting information provided according to the regulations and standards of internal audit?

3. Does the Internal Audit Chamber care about the quality of accounting information that serves internal auditors?

\subsection{Objective}

The study addresses the Sudanese reality, namely the activation of accounting regulations and systems used in the Internal Audit Chamber as well as their application methods, and delivering the individuals training sessions.

\subsection{Methodology}

The study adopted the descriptive approach, the historical approach, hypotheses test as well as the analytical descriptive approach.

\subsection{Limitations}

Temporal Limitations: the study handled the data of Internal Audit Chamber in the Sudanese Ministry of Interior from 2009 to 2017.

Spatial Limitations: the study was conducted at the level of Internal Audit Chamber in the Sudanese Ministry.

\section{Literature Review}

John (1979) audit committees are perceived as guardians of the public interest which provide additional assurance that corporations meet their broad res possibilities of fulfilling the accountability expectations of society, as well as expectations of shareholders and users of financial statements. The ideal audit committee member should be someone who is independent of management, with no significant financial ties to the company, astute in financial matters, possessed of a sense of social res possibility, and adept at resisting board ritual on the one hand and interfering with management on the other.

Management, and not the auditor, should originate information regarding a company's of internal accounting control. The Foreign Corrupt Practices Act of 1977 gives the Securities \&Exchange Commission (SEC) broad res possibilities in the establishment and oversight of internal accounting controls. Audit committees take on an enhanced importance compliance with this Act. 


\section{Ml Macrothink}

International Journal of Accounting and Financial Reporting

ISSN 2162-3082

2019, Vol. 9, No. 4

Monte (2008) showed the design management accounting control systems (MACS) in important factor affecting the extent and success of employee involvement in continuous improvement (CI) programs. The results of an experiment reported here indicate that combination of Activity - Based Cost (ABC) information and an emphasis on idea generation are both important in determining the number of recommendations received. Cost information is important in determining the overhead reduction associated with those recommendations. Furthermore, results - based control leads to less overhead reduction when Volume -Based Cost information (VBC) is provided, but greater average overhead reduction per recommendation when $\mathrm{AB} C$ information is provided.

John (2010) analyses the benefits of accounting regulation and a conceptual framework using an information economics approach that allows consideration of uncertainty, multiple agents, demand for information, and multiple information sources. It also allows private information to enter the analysis. The analysis leads to asset of fundamental properties of accounting information. It is argued that the set of qualitative characteristics typically contained in conceptual frameworks does not adequately aggregate the information demands of users of accounting information. For example, the IASB's conceptual framework contains no guidelines for the trade- off between relevance and reliability. Furthermore, neutrality might not be part of an optimal regulation. The statistical introduced by stewardship use of accounting information is not necessarily undesirable and will always remain; stewardship is the characteristic of accounting information that provides incentives for management to act in the desired way. Accounting information is inherently late compared to other information sources but influences and constrains the content of more timely sources . The accounting system does not exist in a vacuum. Other information sources are present and the purpose of the accounting system cannot be analyzed without considering the existence of other information sources.

Finally, financial statements are audited by an independent auditor.

Hassan (2016) addressed the Role of the Internal Audit on Raising up the Efficiency of Financial and Accounting Performance for Insurance Sector Field study on sample Insurance Companies in the Republic of Sudan and Kingdom of Saudi Arabia, The study aimed at clarifying the role of internal audit to audit quality system important and modem functions tasked to him, presenting the evolution of the conceptual, objective and standards of internal audit.

Assem (2008) aimed at identifying the internal control system applied to the Central Bureau of Statistics in Sudan and its impact on the application of financial regulations.

Hamzeh (2011) aimed at identifying the role of internal audit in monitoring and improving the enterprises' performance as well as the significance of internal audit reports in monitoring their performance.

Sharaf Al-Din (2008) aimed at highlighting the role of internal audit in the public economic units and identifying the global scientific developments in the concept and objectives of internal audit. 


\section{Mll Macrothink}

International Journal of Accounting and Financial Reporting

ISSN 2162-3082

2019, Vol. 9, No. 4

Abd-Alnasser (2002) aimed to identify the factors influencing the effectiveness and competence of accounting information systems in the Jordanian commercial banks.

\section{Theoretical Background}

\subsection{Concept, Definition and Significance of Internal Audit}

Internal audit is a review conducted by the independent auditor of the various departments that are considered when preparing the final accounts that explain the outcome of the work (Hassan, 1985).

- Significance of Internal Audit: it assists the department to carry out its responsibilities properly (Salih, 2007). It also assesses the role of internal control.

- Principles of Internal Audit: Successful performance of Internal Audit Chamber depends on its independence degree, i.e. the auditor has an absolute independence as well as a high level of quality when reviewing the documents and books (Mansour, 1989).

- Internal Audit Services: training the staff on systems and audit procedures, continuous examination as well as evaluation, and urging the staff to carry out their duties accurately (Mohamed, 2005).

- Internal Auditing Standards and Procedures: The American Institute Of Certified Public Accountants has identified a number of general standards relating to the auditor, including scientific, practical and independent qualifications that enable him to perform well with no pressure from any party, the initial screening criteria relating to the preparation of the programs prior to auditing process, the quality of procedures, examination and collection of the appropriate and sufficient evidences. (Zaher, 2009), the professional standards concerning the performance of internal audit professionally as well as acquiring the experience, skills and adequate supervision of internal audit (Mohamed et al. 2002), and the standards of internal audit role representing in planning, accuracy and follow-up of audit ( Mohammed, 1981).

\subsection{Accounting Information}

\subsubsection{Concept, Significance and Characteristics}

Management needs realistic, accurate and timely accounting information that helps to make good decisions. Data are abstract facts that have neither meaning nor significance. Whereas, information is data processed to give the meaning that assists the user in the future processes of decision making (Abd Alrazek, 2004). It is also data processed to make sense for its users (Ahmed, 2004).

Accounting information has to be appropriate with the department's requirements. It also should be properly processed, accurate, comprehensive, and available. 


\section{MInstitute Macrothink $_{\text {Int }}$}

International Journal of Accounting and Financial Reporting

ISSN 2162-3082

3.2.2 Historical Background of the Sudanese Ministry of Interior

Ministry of Interior is one of the sovereign ministries established according to the Presidential Decree No. (35) of 2005 (ministerial decree of 2005). It is very important in Sudan because it keeps security as well as stability and enforces the state authority.

\subsubsection{Administrative and Regulatory Structure of Ministry of Interior}

It consists of eleven police departments and offices, seven bodies divided into thirty departments; each department consists of a large number of units. Thus, the structure of the Ministry of the Interior represents a hierarchy of responsibilities and tasks from the high to low rank (Karar, 2017).

3.2.4 Establishment and Development of Internal Audit Chamber at the Sudanese Ministry of Interior

Internal Audit Chamber at the Ministry of Interior underwent several stages helped to establish an integrated department of internal audit within the ministry.

- $\quad$ First Stage

Internal audit was a small office chaired by the director of financial affairs to review the financial budget. This office was presided by the police and the units that supervise the implementation of financial regulations and laws.

- $\quad$ Second Stage

Internal Audit Chamber was established at the Ministry of Interior in 1986. An officer was appointed to oversee the department that was one of financial affairs departments as well.

- Third Stage

On 23/8/1989, by virtue of decree No. 62 of session No.(1) between the leader of Sudanese coup d'état and the Council of Ministers, in which a decree was issued to urge each minister to establish an internal audit department. Accordingly, the minister of interior issued the decree No.(51) of 1989 defining the subordination of internal audit.

- $\quad$ Fourth Stage

In 1990, ministerial decree No. (33) revised decree No. (51), to stipulate that internal audit administratively reports to the Minister's office in order to assist the General Director of Financial Affairs.

- $\quad$ Fifth Stage

In 1995, ministerial decree No. (37) renewed technical as well as administrative subordination of internal audit to the Minister of the Interior.

- Sixth Stage

By virtue of decree No. (73) of 1995, Internal Audit Chamber has opened the following branches: 


\section{Mll Macrothink}

1. Post-Service Department

2. General Administration of Medical Services

3. General Administration of Police Security

4. General Administration of Traffic

5. General Administration of Passports

6. General Administration of Civil Registry

7. General Administration of Central Investigation.

- Seventh Stage

Ministerial decree No. (160) was issued in September, 2002 as a modification of the ministerial decree No. (225) of 2001. It stipulates that an independent department, called Internal Audit Chamber as well as administratively and technically run by a general manager reporting to the Minister of the Interior, is established in the ministry. This decree represents the beginning of Internal Audit Chamber that expanded to include 83 first lieutenants who obtained training to be qualified for their new job. In addition, its regulation as well as guidebook was prepared.

\subsection{Objectives of Internal Audit in the Ministry of the Interior}

1. Assist the administration to make the plans that contribute to decision making.

2. Ensure due process of books and records and discover forgery methods.

3. Follow the documentary cycle and address mistakes.

\subsection{Bylaws and Acts}

1. Internal audit bylaw of the state departments in 1997.

2. Internal audit bylaw and guidebook in the ministry.

3. Financial Procedures Act of 1997, which was amended in 2007.

4. Act of non-commissioned officers and soldiers' pension.

5. Police forces act.

6. Decrees approved by the minister of interior, the general director of police forces and the directors of public administrations.

\subsection{Confidentiality}

Procedures as well as work in Internal Audit Chamber and its branches are confidential. Internal auditors must ensure accounting information confidentiality and keep records in a safe place. 


\section{MlMacrothink}

International Journal of Accounting and Financial Reporting

ISSN 2162-3082

2019, Vol. 9, No. 4

\subsection{Field Study Procedures}

The author explained the method and procedures to include the population and sample of the study. The sample was randomly selected from the population through distributing (60) questionnaires to the participants who responded, rating $100 \%$.

The questionnaire comprises two main sections:

Section 1: it includes the participants' personal data, such as gender, age, experience, qualification, job title, and area of specialization.

Section II: It comprises (9) phrases analyzed according to Likert five- point scale which consisting of five items (agree, strongly agree, undecided, disagree, strongly disagree). Phrases have been distributed to the three hypotheses.

1. Analysis of the questionnaire items.

a. Personal Data

1. Gender

Table 1. Frequency distribution of the participants according to gender

\begin{tabular}{lll}
\hline Variable & Frequency & Percentage \\
\hline Male & 41 & $68.3 \%$ \\
\hline Female & 19 & $31.7 \%$ \\
\hline Total & 60 & $100 \%$ \\
\hline
\end{tabular}

Source By the author, adopting data of questionnaire in 2018

2. Age

Table 2. Frequency distribution of the participants according to age

\begin{tabular}{lll}
\hline Age Groups & Number & Percentage \\
\hline 35 and less years & 29 & $48.3 \%$ \\
\hline $36-45$ years & 22 & $36.7 \%$ \\
\hline years 55-46 & 8 & $13.3 \%$ \\
\hline 56 and more & 1 & $1.7 \%$ \\
\hline Total & 60 & $100 \%$ \\
\hline
\end{tabular}

Source: By the author, adopting data of questionnaire in 2018 
3. Qualification

Table 3. Frequency distribution of the participants according to qualification

\begin{tabular}{lll}
\hline Qualification & Number & Percentage \\
\hline Bachelor & 32 & $53.3 \%$ \\
\hline Higher Diploma & 4 & $6.7 \%$ \\
\hline Master & 15 & $25.0 \%$ \\
\hline Others & 9 & $15.0 \%$ \\
\hline Total & 60 & $100 \%$ \\
\hline
\end{tabular}

Source: By the author, adopting data of questionnaire in 2018

4. Area of Specialization

Table 4. Frequency distribution of the participants according to specialization

\begin{tabular}{lll}
\hline Area of Specialization & Number & Percentage \\
\hline Accounting & 46 & $76.7 \%$ \\
\hline Economics & 2 & $3.3 \%$ \\
\hline Business Administration & 2 & $3.3 \%$ \\
\hline Studies of Banker & 4 & $6.7 \%$ \\
\hline Others & 6 & $10.0 \%$ \\
\hline Total & 60 & $100.0 \%$ \\
\hline
\end{tabular}

Source: By the author, adopting data of questionnaire in 2018

5. Job Title

Table 5. Frequency distribution of the participants according to job title

\begin{tabular}{lll}
\hline Job title & Percentage & Number \\
\hline Internal auditor & $33.3 \%$ & 20 \\
\hline Financial Manager & $15.0 \%$ & 9 \\
\hline Accountant & $36.7 \%$ & 22 \\
\hline Others & $15.0 \%$ & 9 \\
\hline Total & $100.0 \%$ & 60 \\
\hline
\end{tabular}

Source: By the author, adopting data of questionnaire in 2018 


\section{Experience Years}

Table 6. Frequency distribution of the participants according to experience years

\begin{tabular}{lll}
\hline Percentage & Percentage & Number \\
\hline Less than 5 years & $28.3 \%$ & 17 \\
\hline $5-10$ years & $28.3 \%$ & 17 \\
\hline $11-16$ years & $25.0 \%$ & 15 \\
\hline $17-22$ years & $18.3 \%$ & 11 \\
\hline Total & $100.0 \%$ & 60 \\
\hline
\end{tabular}

Source: By the author, adopting data of questionnaire in 2018

\section{Analysis of Questionnaire Items and Hypotheses Test}

$1^{\text {st }}$ hypothesis: There is a statistically significant relationship between internal audit and control of accounting information, which leads to performance development in service projects in the Sudanese Ministry of the Interior.

Table 7. Frequency and percentages of the participants' responses to the items of the first hypothesis

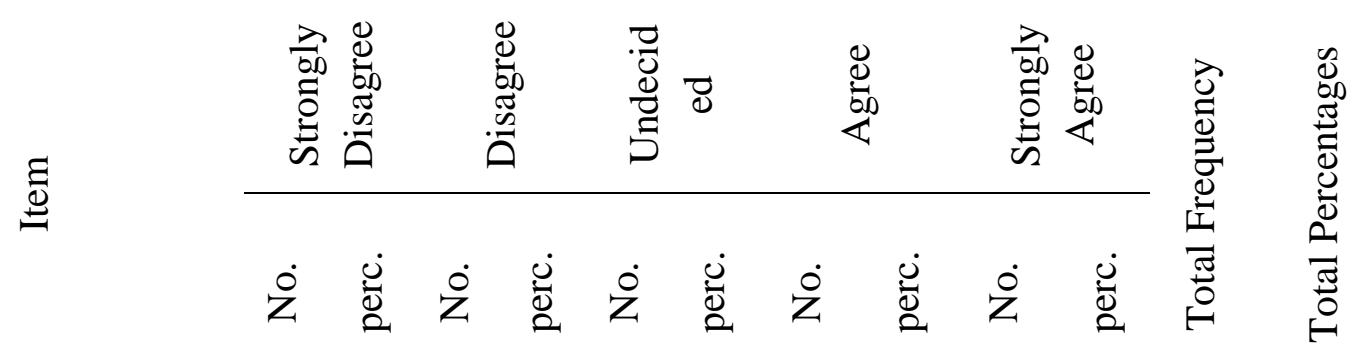

$\begin{array}{lllllllllllll}\text { Giving more concern } & 0 & 0 & 3 & 5 & 6 & 10 & 27 & 45 & 24 & 40 & 60 & 100 \%\end{array}$ to the role of the internal audit raises the productive efficiency of service projects.

$\begin{array}{lllllllllllll}\text { Accounting } & 3 & 5.0 & 0 & 0 & 1 & 30 & 30 & 50 & 9 & 15 & 60 & 100 \% \\ \text { information system } & & & & & 8 & & & & & & & \\ \text { results in evaluating } \\ \text { internal audit and }\end{array}$


positively affects

performance of service

projects in the

ministry

\begin{tabular}{|c|c|c|c|c|c|c|c|c|c|c|c|c|}
\hline $\begin{array}{l}\text { Compliance } \\
\text { accounting } \\
\text { information control } \\
\text { increases } \\
\text { effectiveness } \\
\text { financial performance } \\
\text { as well as the } \\
\text { development } \\
\text { service projects }\end{array}$ & 0 & 0 & 3 & 5.0 & 9 & 15 & 39 & 65 & 9 & 15 & 60 & $100 \%$ \\
\hline
\end{tabular}

Source: the author, field study, 2018

Table 7 indicates that the majority of participants agree with the items in the table; i.e. their responses are positive and reveal that there is a statistically significant relation between internal audit and accounting information control in the Ministry of Interior.

$2^{\text {nd }}$ hypothesis: There is a statistically significant relation between the quality of accounting information and compliance with the systems and regulations of the internal audit.

Table 8. Frequency and percentages of the participants' responses to the items of the second hypothesis

\begin{tabular}{|c|c|c|c|c|c|c|c|c|c|c|c|c|}
\hline \multirow[b]{2}{*}{$\underset{\Xi}{\Xi}$} & \multicolumn{2}{|c|}{ 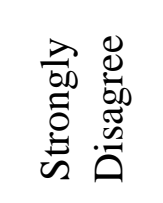 } & \multicolumn{2}{|c|}{ 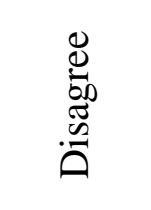 } & \multicolumn{2}{|c|}{ 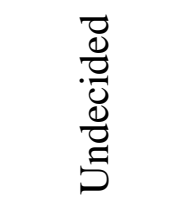 } & \multicolumn{2}{|c|}{ 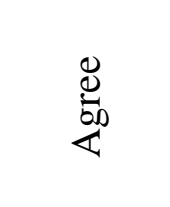 } & \multicolumn{2}{|c|}{ 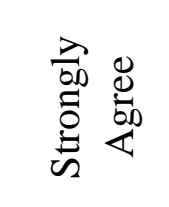 } & \multirow{2}{*}{ 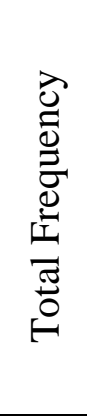 } & \multirow{2}{*}{ 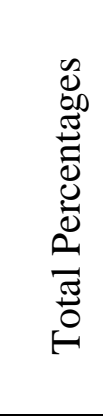 } \\
\hline & $\dot{\mathrm{z}}$ & 巳ั0 & $\dot{\mathrm{z}}$ & $\begin{array}{l}0 \\
\text { ¿ }\end{array}$ & $\dot{0}$ & 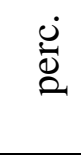 & $\dot{0}$ & $\begin{array}{l}\stackrel{0}{0} \\
\stackrel{0}{2}\end{array}$ & $\dot{\mathrm{z}}$ & $\begin{array}{l}\dot{0} \\
0\end{array}$ & & \\
\hline $\begin{array}{l}\text { Accounting } \\
\text { information } \\
\text { compliance with the } \\
\text { systems and } \\
\text { regulations of internal } \\
\text { audit provides the } \\
\text { quality of internal } \\
\text { audit }\end{array}$ & 3 & 5 & 0 & 0 & 15 & 25 & 18 & 30 & 24 & 40 & 60 & $100 \%$ \\
\hline $\begin{array}{l}\text { Adoption of internal } \\
\text { audit rules raises }\end{array}$ & 0 & 0 & 0 & 0 & 15 & 25 & 0 & 0 & 45 & 75 & 60 & $100 \%$ \\
\hline
\end{tabular}




\section{I Macrothink}

compliance with the ethics and rules of accounting information

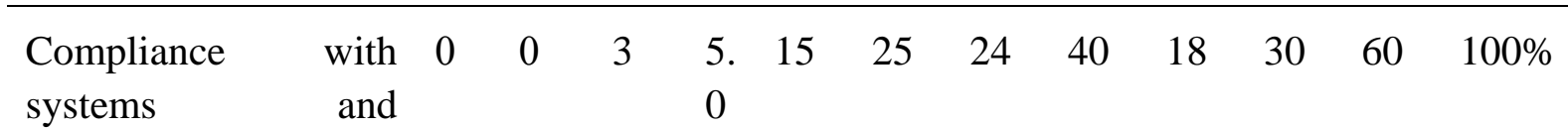

regulations of internal

audit provides more

credible financial

reports.

Source: the author, field study, 2018

Table (8) indicates that the majority of participants agree with the items in the table; i.e. their responses are positive and reveal that there is a statistically significant relation between the quality of accounting information and compliance with the systems and regulations of the internal audit.

$3^{\text {rd }}$ hypothesis: There is a statistically significant relation between the internal auditors' training on accounting information and the improvement of financial performance efficiency.

Table 9. Frequency and percentages of the participants' responses to the items of the third hypothesis

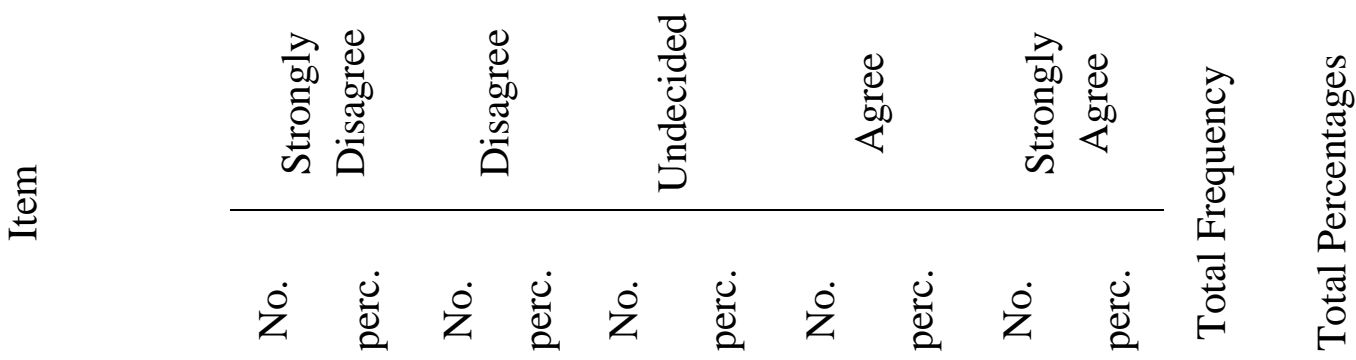

$\begin{array}{llllllllllllll}\text { Qualification } & \text { and } & 3 & 5 & 0 & 0 & 15 & 25 & 18 & 30 & 24 & 40 & 60 & 100 \%\end{array}$
preparation of the

Personnel in Internal

Audit Chamber

creates the quality of

financial performance.

Ongoing training on 0
using Accounting




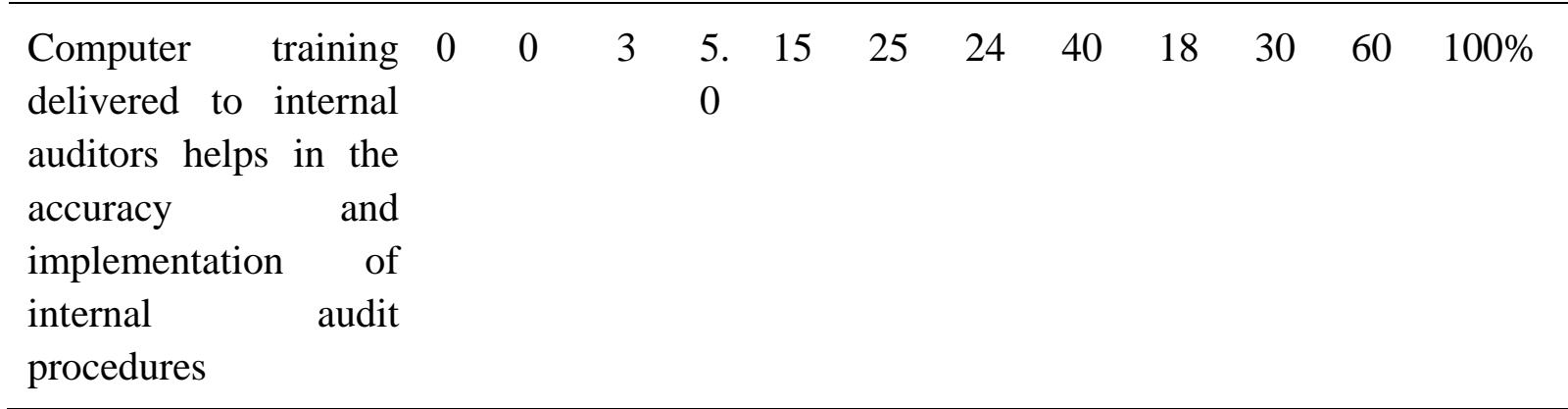

Source: the author, field study, 2018

Table 9 indicates that the majority of participants agree with the items in the table; i.e. their responses are positive and reveal that there is a statistically significant relation between the internal auditors' training on accounting information and the improvement of financial performance efficiency.

\section{Results}

1. Internal audit applies some systems and regulations that contribute to accounting information control.

2. Internal audit system of the Ministry provides accurate accounting data and information as well as financial reports with high quality.

3. Internal audit system helps detect financial malfeasance and control accounting information.

4. Accounting information control system provides accurate, credible and transparent financial reports.

\section{Recommendations}

1. Giving more concern to the adoption of accounting information control to get accurate and transparent financial reports.

2. Using other control systems to identify the accounting information that contradicts the estimated budgets.

3. Compliance with bylaws, procedures and regulations of internal audit.

\section{References}

Abd Alrazek, M. K. (2004). Analysis and design of accounting information systems. Dar Al-Thaqafa for Publishing and Distribution.

Abd-Alnasser, A. K. (2002). Analysis of the factors affecting the efficiency and effectiveness of accounting information systems in Jordanian commercial banks. Unpublished master's thesis, Al al-Bayt University, Al Mafraq.

Ahmed, H. A. (2004). Accounting information systems, intellectual framework and applied systems. Al-Daar Al-Gamiaa, Alexandria. 


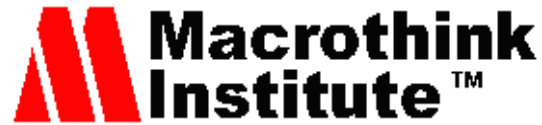

International Journal of Accounting and Financial Reporting

ISSN 2162-3082 2019, Vol. 9, No. 4

Assem, M. M. O. (2008). Effect of the internal control system on compliance with regulations in the Sudanese public departments by application to Central Bureau of Statistics. Unpublished master's thesis, Sudan University of Science and Technology, Khartoum.

Hamza, B. J. A. (2011). Role of internal audit in performance improvement. Unpublished master's thesis, Sudan University of Science and Technology, Khartoum.

Hassan, A. (2016) The Role of the Internal Audit on Raising up the Efficiency of Financial and Accounting Performance for Insurance Companies in the Republic of Sudan and Kingdom of Saudi Arabia. Unpublished BA paper, University of Science and Technology, Omdurman Sudan.

Hassan, M. H. A. (1985). Studies in internal audit $\left(2^{\text {nd }}\right.$ ed.). Cairo: Dar Al-Thaqafa Al-Arabia.

John, C. (2010). Conceptual frameworks of accounting from an information perspective. Accounting and Business Research, 40(3).

John, S. (1979). Internal Auditor's Role in Internal Controls the Auditing Committee - A public Accountant's. Journal of Accountancy, 147(4).

Karrar, M. K. (2017). Internal audit in Ministry of Interior: An interview.

Mansour, H. M. (1989). Lecture on audit. Cairo: Daar Al-Thaqafa Al-Arabia for publication and distribution.

Mohamed, A. (2005). Internal audit in the light of companies computerization research. First Arab Conference, Cairo.

Mohamed, A. S., \& Shehata, A. S. (2002). Control and internal audit. Alexandria University: Open Education Unit, Faculty of Commerce (pp.127-128).

Mohamed, M. K. (1981). Lessons on audit. Cairo: Dar Al-Fakr Al-Arabi.

Monte, W. (2008). The design of management accounting control systems (MACS) is an important. Australian Journal of Management, 33(2).

Rafat, A. R. (1985). Current practices of internal audit and Egyptian corporate. Scientific Journal of College of Commerce, (8), 2.

Saleh, M. K. (200). Internal Control Conference: Reality and Endowments. Tripoli: The Academic House for Printing and publication.

Sharaf Al-Din, M. K. (2008). Internal audit and its role in achieving total quality management in public economic departments with an application to the National Electricity Authority. Unpublished doctorate's thesis, Sudan University of Science and Technology, Khartoum.

Zaher, A. S. (2009). Auditing. Amman: Dar Al-Raya.

\section{Decrees}

Ministerial Decree No. (35) of 2005. 


\section{Macrothink \\ International Journal of Accounting and Financial Reporting ISSN 2162-3082 2019, Vol. 9, No. 4}

Ministerial Decree No. (62) of 1989.

Ministerial Decree No. (51) of 1989.

Ministerial Decree No. (33) of 1990.

Ministerial Decree No. (37) of 1995.

Ministerial Decree No. (73) of 1995.

Ministerial Decree No. (160) of 2002.

Financial Bylaws of 1999, Ministry of Interior, Publication No. 5/99.

\section{Copyright Disclaimer}

Copyright for this article is retained by the author(s), with first publication rights granted to the journal.

This is an open-access article distributed under the terms and conditions of the Creative Commons Attribution license (http://creativecommons.org/licenses/by/4.0/) 